\title{
ANALISIS KOHESI ANAFORA DAN KATAFORA PADA TAJUK RENCANA KORAN KOMPAS
}

\author{
Endang Wiyanti, Yulian Dinihari \\ Universitas Indraprasta PGRI \\ E-mail: endangwiyanti76@gmail.com, yuliandini07@gmail.com
}

Naskah diterima: 30 Januari 2017; direvisi: 18 April 2017; disetujui: 21 April 2017

\begin{abstract}
The purpose of this study was to determine the cohesion aspect anaphora and katafora the Kompas newspaper editorials. The method used in this study is qualitative content analysis with technical analysis is a method used to examine in greater depth discourse. The results showed that of the 12 editorial discourse data showed as many as 164 pairs of sentences. Research data of 164 couples found 67 sentences have cohesion anaphora or as much as 40,48\% and only 14 pairs sentence with katafora cohesion or 8,54\%. Aspects of cohesion anaphora is used predominantly in building cohesion sentence. From the use of markers, can be show that demonstrative pronouns as much as 54,32\% more often appear in a sentence with cohesion. It indicates that the demonstrative pronoun marker has an important role in forming the sentence cohesion.
\end{abstract}

Keywords: cohesion anaphora and katafora, the Kompas newspaper editorials

\begin{abstract}
ABSTRAK
Tujuan penelitian ini adalah untuk mengetahui aspek kohesi anafora dan katafora pada tajuk rencana koran Kompas. Metode yang digunakan dalam penelitian ini adalah kualitatif dengan teknik analisis konten, yaitu metode yang digunakan untuk meneliti wacana secara lebih mendalam. Hasil penelitian menunjukkan bahwa dari 12 wacana tajuk rencana diperoleh data sebanyak 164 pasangan kalimat. Dari 164 data penelitian ditemukan 67 pasangan kalimat memiliki kohesi anafora atau sebanyak 40,48\% dan hanya 14 pasangan kalimat berkohesi katafora atau 8,54\%. Aspek kohesi anafora digunakan secara dominan dalam membangun kepaduan kalimat. Dari penggunaan pemarkah, dapat ditemukan bahwa pemarkah pronomina demonstratif sebanyak $54,32 \%$ lebih sering muncul dalam kalimat yang berkohesi. Hal ini menunjukkan bahwa pemarkah pronomina demonstratif mempunyai peran penting di dalam membentuk kepaduan kalimat.
\end{abstract}

Kata kunci: kohesi anafora, katafora, tajuk rencana Kompas

\section{PENDAHULUAN}

Pengajaran Bahasa Indonesia pada dunia pendidikan berorientasi pada pengembangan empat aspek keterampilan berbahasa, yaitu membaca, menulis, berbicara, dan mendengarkan. Setiap aspek di atas pada dasarnya mempunyai bobot dan tingkat pemerolehan yang sama. Keempat keterampilan bahasa tersebut hendaknya diberikan kepada peserta didik secara seimbang. Oleh karena itu, pengembangan pembelajaran yang saat ini dikembangkan selalu berdasar pada pembelajaran yang konstektual. 
Guna membangun suasana belajar yang konstektual, diperlukan beberapa metode dan media yang mampu mengantar meningkatnya kemampuan berbahasa peserta didik. Media pembelajaran dikembangkan dengan berbagai cara. Salah satu media yang bisa digunakan sebagai sarana pembelajaran adalah koran. Koran adalah media efektif untuk pengembangan bahasa. Koran dapat pula dijadikan sumber pembelajaran untuk meningkatkan dan mengembangkan keterampilan berbahasa. Berbagai rubrik di koran dapat dikembangkan sebagai sumber dan model pembelajaran, antara lain berita, feature, tajuk rencana, artikel, dan iklan. Model pengembangan pembelajaran ini dapat mengeksplorasi mengenai tata bahasa, gaya bahasa, diksi, bentuk wacana, dan lain sebagainya.

Namun, fenomena dan pengamatan penulis tentang kemampuan menelaah wacana siswa terhadap bahan bacaan koran masih rendah. Sebagian besar siswa masih kurang berminat untuk membaca koran khususnya pada rubrik artikel dan tajuk rencana. Hal tersebut disebabkan antara lain karena kalimat yang cukup sulit dicerna, atau pemilihan kata yang cukup sulit. Kemampuan memahami wacana siswa pun masih cukup rendah, pada pelajaran membaca pemahaman, siswa masih merasa kesulitan untuk menentukan isi, gagasan pokok dan informasi tersirat maupun tersurat pada wacana yang diberikan. Siswa masih sering merasa kesulitan untuk menjawab pertanyaan bacaan, baik pertanyaan dalam bentuk scanning, refering maupun skimming.

Atas dasar itulah penulis melakukan penelitian analisis wacana dengan aspek kohesi. Fokus penelitian ini adalah aspek kohesi anafora dan katafora pada tajuk rencana koran Kompas. Kohesi membangun keutuhan wacana, dan dengan memahami aspek kohesi wacana membantu siswa untuk mengetahui isi wacana secara utuh. Kohesi anafora dan katafora diharapkan mampu meningkatkan siswa memahami isi wacana, terutama untuk menentukan kepaduan yang bersifat referring atau rujukan. Dengan menguasai aspek rujukan atau referring dari wacana, siswa akan lebih mudah mendapatkan pesan inti sebuah wacana.

Tajuk rencana merupakan wacana tulis yang cukup baik karena dalam proses penulisannya selalu didiskusikan oleh redaktur. Baik dari segi pemilihan judul, penyusunan kalimat, pemilihan kata maupun gaya bahasa dilakukan dengan baik dan memenuhi kaidah penulisan dan penggunaan bahasa Indonesia.

Hal inilah yang menjadi pertimbangan penulis untuk melakukan penelitian mengenai aspek kohesi anafora dan katafora pada tajuk rencana koran Kompas. Penelitian ini diharapkan akan mampu membantu siswa memahami isi wacana dan juga untuk mengembangkan model pembelajaran bahasa Indonesia. Alasan lain penulis memilih penelitian ini adalah untuk mendorong siswa memahami aspek bahasa, menelaah wacana tulis, dan menggali informasi dari wacana. Selain itu, Kompas sebagai sebuah surat kabar berskala nasional cukup dikenal andal dalam menyajikan berita, baik, serta santun dalam menyusun bahasa sehingga layak untuk menjadi objek penelitian.

Kohesi gramatikal adalah perpautan bentuk kalimat-kalimat yang diwujudkan dalam sistem gramatikal. Secara lebih khusus, dalam tulisan ini penulis memfokuskan penelitiannya pada aspek kohesi anafora dan katafora. Anafora dan katafora adalah ungkapan kebahasaan yang berupa kata, frasa, atau klausa untuk menunjuk pada kata, frasa, atau klausa yang lain. Kohesi anafora dan katafora dapat menggunakan (1) pronomina persona, (2) pronomina demonstratif, (3) pronomina komparatif sebagai pemarkah atau penanda. Hubungan pemahaman satu kalimat dengan kalimat yang lain dapat dipautkan dengan kohesi anafora dan katafora. Kalimat yang baik hendaknya merupakan kalimat yang berpautan satu dengan lainnya. 
Pada penelitian ini, penulis memfokuskan penelitian aspek kohesi anafora dan katafora pada inti pesan yang ada di dalam keseluruhan tajuk rencana. Sebagaimana diketahui sebuah tajuk rencana pada umumnya terdiri dari pembukaan yang terdapat pada paragraf pertama, inti pesan (pesan utama), dan penutup yang biasanya terdapat pada paragraf terakhir.

Chaer (2010: 34) menjelaskan bahwa, "Wacana sebagai satuan bahasa tertinggi atau terbesar adalah pengertian (gagasan, ide, konsep, dan sebagainya) yang lengkap dan utuh." Dengan kata lain, pesan yang akan disampaikan dapat diterima dengan benar dan tepat.

Untuk menguraikan wacana lebih lanjut terlebih dahulu harus mengetahui klasifikasi wacana. Klasifikasi atau pembagian wacana sangat tergantung dari aspek dan sudut pandang yang digunakan. Mulyana (2005:47) setidaknya membagi wacana menjadi beberapa segi, yaitu (1) bentuk, (2) media, (3) jumlah penutur dan (4) sifat. Selanjutnya dijelaskan bahwa pemilahan wacana bersifat terbuka sesuai dengan perkembangan pemakaian bahasa di dalam masyarakat. Menurut Robert E. Longacre dalam (Mulyana, 2005:47) wacana dapat dibagi menjadi 6 (enam) jenis yaitu, wacana naratif, prosedural, ekspositori, hortarori, epistoleri, dan dramatik. Menurut Tarigan (2009:48), wacana dapat diklasifikasikan dengan berbagai cara, tergantung sudut pandang kita antara lain: (1) berdasarkan tertulis atau tidaknya wacana, (2) berdasarkan langsung atau tidaknya pengungkapan wacana, dan (3) berdasarkan penuturan wacana.

Baryadi (2002:9) mengklasifikasikan berbagai jenis wacana berdasarkan media yang dipakai untuk mewujudkannya, keaktifan partisipasi komunikasi, tujuan pembuatan, bentuk, genre dan isi. Tajuk rencana menurut klasifikasi ini tergolong wacana tulis secara noninteraktif karena proses memproduksinya tidak dapat langsung ditanggapi.
Salah satu aspek yang penting dalam wacana adalah kohesi. Kohesi adalah aspek yang menjelaskan keterkaitan kalimat dengan kalimat, paragraf dengan paragraf, atau bab dalam bab dalam suatu wacana, Keterkaitan antarkalimat ditandai dengan adanya unsur-unsur gramatikal atau semantik secara eksplisit. Kekohesifan di dalam bahasa terjadi karena adanya keterpautan hubungan unsur yang satu dengan unsur yang lain di dalam wacana sehingga terbentuklah pengertian yang koheren. Pada penjelasan sebelumnya telah disebutkan bahwa antara kalimat, klausa, frasa, dan kata dalam suatu wacana biasanya terdapat hubungan bentuk yang saling mengikat sehingga terbentuk suatu keutuhan atau kepaduan. Kepaduan ini disebut kohesi (cohesion).

Untuk membentuk kepaduan sebuah wacana dapat dibangun dengan kohesi leksikal dan kohesi gramatikal. Berbicara mengenai kohesi leksikal tidak dapat dilepaskan dengan hubungan antarmakna dalam kalimat. Hubungan kohesif dalam wacana sering ditandai dengan pemarkah (penanda khusus) yang bersifat linguaformal. Secara khusus penulis memfokuskan pada kohesi gramatikal.

Zaimar (2009:140) menyatakan bahwa kohesi leksikal ditampilkan oleh reiterasi. Dijelaskan bahwa reiterasi adalah pengulangan makna baik seluruhnya atau sebagian. Halliday dan Hasan (dalam Zaimar, 2009:140) menyatakan bahwa ada bermacam-macam reiterasi, yaitu repetisi, sinonim, hampir sinonim, hiponim, dan kata generik.

Dalam kohesi gramatikal, alat yang digunakan berupa unsur-unsur kaidah bahasa. Alat ini digunakan untuk menghubungkan ide antarkalimat. Menurut Halliday dan Hasan (dalam Zaimar, 2009:116) kohesi gramatikal dapat diklasifikasikan dalam beberapa kategori, yaitu referensi, substitusi, dan elipsis.

Rujukan atau referensi adalah salah satu jenis kohesi gramatikal yang berupa satuan lingual tertentu yang mengacu pada satuan lingual lain yang mendahului dan 
mengikutinya. Jenis kohesi ini berfungsi untuk menghubungkan suatu unsur teks dengan hal-hal lain yang berkaitan dengan unsur atau hal yang dirujuk.

Secara tradisional referensi berarti hubungan antara kata dengan benda. Kata buku mempunyai referensi kepada sekumpulan kertas terjilid untuk ditulis atau dibaca. Halliday dan Hasan (1979:31; 1994:76) membagi referensi menjadi dua berdasarkan tempatnya; yaitu referensi eksoforis atau eksafora dan referensi endoforis atau endofora. Referensi eksoforis adalah referensi yang acuannya berada di luar teks wacana. Referensi ini bersifat situasional. Referensi tersebut terjadi apabila digunakannya suatu kata yang mengacu pada suatu kata umum atau situasi yang abstrak di luar teks wacana.

Referensi kedua adalah endoforis. Referensi endoforis adalah referensi yang acuannya berada di dalam teks wacana, yang biasanya diwujudkan oleh pronomina persona, pronomina demonstratif, maupun pronomina komparatif. Menurut arah perujukannya referensi endoforis dibagi menjadi referensi anaforis atau anafora dan referensi kataforis atau katafora.

Kridalaksana dalam (Arifin, 2015:105) mendefinisikan istilah anafora sebagai berikut: "1). Pengulangan bunyi, kata atau struktur sintaksis pada larik-larik atau kalimat-kalimat yang berurutan untuk memperoleh efek tertentu, (2) hal atau fungsi merujuk kembali kepada sesuatu yang telah disebutkan sebelumnya dalam wacana (yang disebut anteseden) dengan pengulangan atau dengan substitusi". Hafizd hari ini tidak masuk sekolah. Ia ikut ibunya pergi ke Medan. Dari contoh di atas, dapat dijelaskan bahwa kata Ia dan nya merujuk pada kata Hafizd. Rujukan tersebut menggunakan kepaduan rujukan anafora dengan penanda pronomina persona.

Referensi katafora termasuk referensi endoforik. Referensi katafora adalah pengacuan pronomina terhadap anteseden yang terletak di kanan. Seperti kulitnya, mata Haarits juga khas, berkelopak besar tanpa garis lipatan. Pronomina -nya pada contoh kalimat di atas merujuk pada kata Haarits, yang berhubungan secara kohesi katafora.

Setiap koran pada umumnya memuat laporan dan liputan peristiwa-peristiwa yang terjadi, ide-ide, opini-opini yang berkembang paling akhir di dunia. Laporan dan peliputan tersebut lazim disebut berita. Selain dari itu, ada satu halaman yang disajikan khusus untuk memberikan karangan yang menyampaikan ide, pemikiran, opini dan tanggapan koran yang bersangkutan terhadap berita yang pernah atau sedang dimuat. Karangan atau tulisan itu sering disebut dengan editorial atau tajuk rencana.

Sebagai suatu wacana tulis, tajuk rencana dituntut memiliki keutuhan struktur wacana. Keutuhan itu sendiri dibangun oleh komponen-komponen yang terjalin di dalam suatu organisisi kewacanaan. Wacana yang utuh adalah wacana yang lengkap, yaitu mengandung aspek-aspek terpadu dan menyatu.

Bahasa jurnalistik atau biasa disebut bahasa pers merupakan ragam bahasa kreatif bahasa Indonesia, dengan demikian bahasa jurnalistik memiliki kaidah-kaidah tersendiri yang membedakan dengan bahasa yang lain. Chaer (2010:2) menyatakan bahwa "bahasa Indonesia ragam jurnalistik mempunyai ciri-ciri sendiri yang membedakan dengan ragam bahasa lainnya". Selanjutnya dijelaskan bahwa ciri-ciri ragam bahasa jurnalistik disesuaikan dengan tujuan tulisan jurnalistik dan siapa pembaca ragam jurnalistik. Ciri ragam bahasa jurnalistik antara satu surat kabar dengan surat kabar lain sering kali memiliki perbedaan, tetapi secara umum ciri ragam bahasa jurnalistik tersebut sama.

Bahasa jurnalistik hadir dan diperlukan oleh wartawan atau insan pers untuk kebutuhan komunikasi efektif dengan pembaca. Oleh karena itu, diperlukan kecermatan dan keterampilan tersendiri di dalam penulisan sebuah berita, features, opini atau tajuk rencana agar komunikasi 
tersebut dapat berjalan dengan lancar, efektif dan tepat sasaran.

\section{METODE PENELITIAN}

Metode yang digunakan dalam penelitian ini adalah metode kualitatif. Endraswara (2004:5) menyatakan bahwa, "penelitian kualitatif adalah penelitian yang dilakukan dengan tidak mengutamakan angka-angka, tetapi mengutamakan kedalaman penghayatan terhadap interaksi antarkonsep yang sedang dikaji secara empiris".

Metode penelitian bahasa berkaitan pula dengan tujuan penelitian serta melibatkan pengumpulan dan pemilihan data (Ratna, 2008: 66-68). Penelitian ini menggunakan metode kualitatif karena penelitian kualitatif adalah penelitian yang paling cocok dengan fenomena sastra. Hal ini perlu dipahami sebab karya sastra adalah dunia kata dan simbol yang penuh makna sehingga perlu diinterpretasikan maknanya agar mudah dimengerti dan dipahami.

Penelitian ini adalah penelitian kualitatif dengan analisis isi (content analysis). Penelitian metode kualitatif dengan content analysis yaitu metode yang digunakan untuk meneliti wacana secara lebih mendalam. Objek penelitian adalah seluruh tajuk rencana koran Kompas yang dimuat pada tahun 2010, yaitu kurang lebih sebanyak 310 tajuk rencana karena pada hari Minggu dan hari besar nasional tidak dimuat, sedangkan yang menjadi fokus penelitian adalah aspek kohesi anafora wacana tajuk rencana koran Kompas yang dimuat pada minggu pertama bulan Mei dan minggu keempat bulan Juli 2010 atau sebanyak 12 tajuk rencana. Waktu penelitian berlangsung selama lima bulan, dari September 2016 sampai Januari 2017. Berikut adalah tabel sumber data yang menjadi objek penelitian penulis.

Tabel 1. Sumber Data

\begin{tabular}{cllccc}
\hline No & \multicolumn{1}{c}{ Judul Tajuk Rencana } & \multicolumn{1}{c}{ Tgl. Terbit } & $\begin{array}{c}\text { Jml } \\
\text { Par. }\end{array}$ & Jml Pas. Kal. & $\begin{array}{c}\text { Kode } \\
\text { Judul }\end{array}$ \\
\hline $\mathbf{1}$ & Expo dan Pengakuan atas China & Senin, 3 Mei 2010 & 8 & 11 & A \\
\hline $\mathbf{2}$ & Dana Talangan untuk Yunani & Selasa, 4 Mei 2010 & $\mathbf{1 0}$ & $\mathbf{6}$ & B \\
\hline $\mathbf{3}$ & Pergolakan di Atap Dunia & Rabu, 5 Mei 2010 & $\mathbf{7}$ & $\mathbf{1 3}$ & $\mathbf{C}$ \\
\hline $\mathbf{4}$ & Peringatan Keras bagi AS & Kamis, 6 Mei 2010 & $\mathbf{9}$ & $\mathbf{1 3}$ & D \\
\hline $\mathbf{5}$ & Masihkah Raja Jadi Penentu & Jumat, 7 Mei 2010 & $\mathbf{8}$ & $\mathbf{1 2}$ & E \\
\hline $\mathbf{6}$ & Partai Harus Berkoalisi & Sabtu, 8 Mei 2010 & $\mathbf{1 1}$ & $\mathbf{6}$ & F \\
\hline $\mathbf{7}$ & Perubahan Cuaca dan Perencanaan & Senin, 19 Juli 2010 & $\mathbf{8}$ & $\mathbf{1 8}$ & G \\
\hline $\mathbf{8}$ & Lalu Lintas Menyeramkan & Selasa, 20 Juli 2010 & $\mathbf{1 1}$ & $\mathbf{1 5}$ & H \\
\hline $\mathbf{9}$ & Menyelamatkan Bumi Kita & Rabu, 21 Juli 2010 & $\mathbf{1 0}$ & $\mathbf{1 5}$ & I \\
\hline $\mathbf{1 0}$ & Pengisian Jabatan Publik & Kamis, 22 Juli 2010 & $\mathbf{8}$ & $\mathbf{1 5}$ & J \\
\hline $\mathbf{1 1}$ & Lindungi Anak-Anak Kita & Jumat, 23 Juli 2010 & $\mathbf{1 1}$ & $\mathbf{1 7}$ & K \\
\hline $\mathbf{1 2}$ & Terjebak Politik Dagang & Sabtu, 24 Juli 2010 & $\mathbf{8}$ & $\mathbf{2 3}$ & L \\
\hline & Jumlah & $\mathbf{1 2}$ & $\mathbf{9 8}$ & $\mathbf{1 6 4}$ & \\
\hline
\end{tabular}

\section{Keterangan:}

- Pas.Kal. : Jumlah Pasangan Kalimat

- Jml Par. : Jumlah Paragraf

Dari tabel di atas, diketahui bahwa dari 12 wacana tajuk rencana diperoleh data sebanyak 164 pasangan kalimat. Pasangan kalimat tersebut digunakan sebagai bahan analisis data aspek kohesi anfora dan katafora untuk membentuk kalimat yang padu.

Analisis tersebut mencakup: deskripsi data aspek kohesi anafora dan katafora per wacana tajuk rencana/judul, dan (2) deskripsi data aspek kohesi anafora 
dan katafora seluruh wacana tajuk rencana/judul yang diteliti. Teknik pengumpulan data yang dilakukan adalah dengan membaca tajuk rencana yang terbit di koran Kompas berkali-kali. Dari hasil membaca ini ditemukan beberapa bentuk kohesi baik kohesi leksikal maupun gramatikal. Dalam hal ini penulis hanya melakukan penelitian pada kohesi anafora dan katafora dan memindahkannya ke dalam tabel analisis.

Penelitian ini menggunakan dua jenis teknik analisis data, yaitu deskripsi eksploratif dan deskripsi analisis. Deskripsi eksploratif adalah analisis yang dilakukan dengan cara membaca secara intensif untuk menemukan pesan yang terkandung di dalam kalimat dan menemukan struktur kalimat sehingga dapat dilakukan analisis sesuai dengan tujuan penelitian. Deskripsi analisis adalah analisis yang dilakukan dengan cara mencermati, mengkaji, mengeksplisitkan, dan mensistemasikan unsur-unsur yang ada di dalam objek penelitian, yaitu wacana tajuk rencana, yaitu: (a) menganalisis aspek kohesi anafora dan katafora antarkalimat dalam tiap paragraf dengan teknik agency pairs (pasangan kalimat), lalu memasukkannya ke dalam tabel analisis; (b) mengklasifikasikan penanda kohesi anafora dalam kalimat berpasangan dengan cara kalimat kedua sebagai kalimat penguji dari kalimat pertama; (c) merekapitulasi hasil temuan dan menyimpulkan hasil penelitian.

\section{HASIL DAN PEMBAHASAN}

Data yang diteliti sebanyak 12 tajuk rencana koran Kompas yang terbit dari bulan Mei sampai dengan bulan Juli 2010 dari 12 wacana tajuk rencana diperoleh data sebanyak 164 pasangan kalimat. Pasangan kalimat tersebut digunakan sebagai bahan analisis data aspek kohesi anafora dan katafora untuk membentuk kalimat yang padu. Analisis tersebut mencakup, (1) deskripsi data aspek kohesi anafora dan katafora per wacana tajuk rencana/judul, dan (2) deskripsi data aspek kohesi anafora dan katafora seluruh wacana tajuk rencana/judul yang diteliti. Berikut adalah data hasil analisis yang disajikan sebagai berikut.

\section{Deskripsi Data Analisis Aspek Kohesi Anafora dan Katafora Per Tajuk Rencana}

\section{Data 1. Deskripsi Data Analisis Tajuk Rencana I : Expo dan Pengakuan atas China \\ Contoh: Data 6 \\ Pasangan 6}

1. Melalui pameran besar ini, China juga tidak malu-malu lagi ingin memperlihatkan kepada dunia tentang kemampuannya dalam pembangunan ekonomi, ilmu pengetahuan, dan teknologi.

2. China ingin berkata kepada dunia tentang kebangkitan ekonominya.

\section{Analisis}

Kata nya pada kata ekonominya pada kalimat kedua merujuk pada kata China pada kalimat pertama, berhubungan secara anafora pronomina persona.

\section{Aspek Katafora}

Data di atas menunjukkan bahwa teks tajuk rencana tersebut memiliki 2 pasangan kalimat yang mempunyai aspek kohesi katafora. Aspek kohesi tersebut terdapat pada pasangan kalimat 1 dan 5. Pemarkah yang digunakan adalah pronomina demonstratif. Pemarkah tersebut penting untuk menunjukkan hubungan antarkalimat sehingga membentuk kepaduan.

Contoh: Data 5

Pasangan 5

1. Pemerintah China hendak memperlihatkan kepada masyarakatnya sendiri tentang pencapaian yang diraih selama ini, terutama setelah gerakan pembaruan sejak tahun 1978 oleh Deng Xiaoping.

2. Expo digunakan sebagai momentum untuk meningkatkan keyakinan dan kepercayaan diri di kalangan ma- 
syarakat China tentang kemampuan mendorong percepatan pembangunan.

\section{Analisis}

Kata ini pada kalimat pertama merujuk pada frasa kemampuan mendorong percepatan pembangunan pada kalimat kedua, berhubungan secara katafora pronominal demonstratif.

Data 2. Deskripsi Data Analisis Tajuk Rencana II: Dana Talangan untuk Yunani

\section{Contoh: Data 16}

Pasangan 16

1. Krisis Yunani dan sejumlah negara zona euro lain, seperti diungkapkan pengamat, jadi batu ujian bagi kredibilitas sistem mata uang tunggal Eropa.

2. Krisis ini lambat tertangani dan menyeret zona euro antara lain karena tak ada mekanisme yang memungkinkan UE dengan cepat melakukan penalangan, atau memungkinkan Yunani mendevaluasikan mata uang atau bahkan keluar dari keanggotaan zona euro.

\section{Analisis}

Kata ini pada pada kalimat kedua merujuk pada kata frasa krisis Yunani, berhubungan secara anafora pronominal demonstratif.

\section{Aspek Katafora}

Aspek kohesi katafora yang terdapat pada teks tajuk rencana II menggunakan pemarkah pronomina demonstratif. Dari seluruh pasangan kalimat teks tajuk rencana di atas hanya mempunyai satu pasangan kalimat yang dipadukan dengan kohesi katafora yaitu psangan kalimat 12 . Hal ini menunjukkan bahwa dalam membangun kepaduan kalimatnya, penulis kurang memfokuskan pada aspek kohesi tersebut.

Contoh: Data 12

Pasangan 12

1. Krisis di zona euro ini mengingatkan kita pada krisis finansial Asia 1997.
2. Krisis utang pemerintah yang berawal di Yunani dengan cepat menyebar ke Portugal, Spanyol, Irlandia (bahkan, mungkin Italia) dan beresiko menyeret seluruh perekonomian zona euro dan perekonomian global yang belum sepenuhnya pulih dari krisis.

\section{Analisis}

Kata ini pada kalimat pertama merujuk pada frasa di Yunani, Portungal, Spanyol, Irlandia pada kalimat kedua, berhubungan secara katafora pronomina demonstratif.

Data 3. Deskripsi Data Analisis Tajuk Rencana III: Pergolakan di Atap Dunia Contoh: Data 30

Pasangan 30

1. Keheningan Nepal sebagai negeri di atap dunia, yang ratusan tahun di bawah tradisi asketik dan meditatif Hindu, benar-benar buyar sejak kaum Maois melancarkan pemberontakan pada tahun 1996.

2. Keadaan negeri berpenduduk 22 juta itu tidak lebih baik karena kaum Maois terus bertingkah meski sudah meletakkan senjata.

\section{Analisis}

Kata itu pada kalimat kedua merujuk pada kata Nepal pada kalimat pertama, berhubungan secara anafora pronomina demonstratif.

\section{Aspek Katafora}

Teks tajuk rencana tersebut di atas tidak mempunyai aspek kohesi katafora. Jadi, dapat dikatakan bahwa aspek kohesi katafora bukan merupakan hal penting untuk memadukan hubungan antarkalimat bagi penulis tajuk rencana tersebut.

\section{Data 4. Deskripsi Data Analisis Tajuk Rencana IV: Peringatan Keras bagi AS Contoh: Data 41 \\ Pasangan 41}

3. Pelaku bukanlah orang luar, tetapi warga negara AS sendiri yang kelahiran Pakistan 
4. Apa pun asal keturunan pelaku, dia adalah warga AS.

\section{Analisis}

Kata dia pada kalimat keempat merujuk pada kata pelaku pada kalimat ketiga berhubungan secara anafora pronomin persona

\section{Aspek Katafora}

Aspek kohesi katafora meski tidak dominan terdapat di dalam teks tajuk rencana tersebut di atas, namun dengan adanya 3 pasangan kalimat yang memiliki kepaduan kohesi anafora menunjukkan bahwa aspek kohesi tersebut cukup penting guna memadukan kalimat. Pemarkah yang digunakan adalah pronomina persona 1 pemarkah dan pronomina demonstratif sebanyak 2 pemarkah

Contoh: Data 36

Pasangan 36

1. Sejak saat itu, sejumlah usaha penyerangan terhadap AS berkali-kali dilakukan.

2. Sebagai contoh, pada tahun 2001 sejumlah amplop surat beracun yang berisi bubuk antraks dikirimkan kepada para senator dan media.

\section{Analisis}

Kata itu pada kalimat pertama merujuk pada frasa tahun 2001, berhubungan secara katafora pronomina demonstratif.

Data 5. Deskripsi Data Analisis Tajuk Rencana V: Masihkan Raja jadi

\section{Penentu}

\section{Contoh: Data 46}

Pasangan 46

1. Itulah sebabnya polarisasi Thailand yang sekarang ini terlihat begitu parah membutuhkan adanya tindakan mendesak untuk mengatasinya dari tokoh independen, baik dari dalam maupun dari luar Thailand.

2. Kalau Thailand mau membuka diri, sudah tiba saatnya negeri ini membuka pintu lebar-lebar bagi negara-negara sahabat, seperti yang tergabung dalam
ASEAN, untuk membentu menyelesaikan masalah.

\section{Analisis}

Kata ini pada kalimat kedu merujuk pada kata Thailand pada kalimat pertama berhubungan secara anafora pronomina demonstratif.

\section{Aspek Katafora}

Dari data Pada tabel 4.5. diperoleh informasi bahwa teks tajuk rencana di atas mempunyai dua pasangan kalimat yang dipadukan dengan kohesi katafora. Pemarkah yang digunakan adalah pronomina demonstratif, hal ini menunjukkan bahwa pronomina demonstratif penting guna memadukan kalimat.

Contoh: Data 48

Pasangan 48

1. Selama ini yang diyakini di Thailand adalah raja sebagai pilar stabilitas negara, dan sejarah telah membuktikan hal itu.

2. Mengutip pendapat Michael RK Vatikiotis, hingga kini rakyat Thailand tetap menganggap raja sebagai dewa yang menjelma menjadi manusia.

\section{Analisis}

Kata itu pada kalimat pertama merujuk pada frasa rakyat Thailand tetap menganggap raja sebagai dewa yang menjelma menjadi manusia pada kalimat kedua, berhubungan secara katafora pronomina demonstratif.

\section{Data 6. Deskripsi Data Analisis Tajuk} Rencana VI: Partai Harus Berkoalisi

Contoh: Data 61

Pasangan 61

1. Bila partai-partai sulit untuk berkompromi membentuk pemerintahan koalisi, tentu kondisi tersebut akan membawa Inggris ke situasi sulit.

2. Oleh karena itu, kalau tidak tercapai kesepakatan membentuk pemerintahan koalisi, pemilu baru harus dilakukan. 


\section{Analisis}

Kata itu pada kalimat kedua merujuk pada frasa kondisi tersebut pada kalimat pertama, berhubungan secara anafora pronomina demonstratif.

\section{Aspek Katafora}

Aspek kohesi katafora tidak terdapat dalam teks tajuk rencana di atas. Dapat disimpulkan bahwa penulis tajuk rencana kurang mengganggap penting aspek kohesi katafora pada teks tajuk rencana tersebut.

\section{Data 7. Deskripsi Data Analisis Tajuk Rencana VII:Perubahan Cuaca dan Perencanaan}

Contoh: Data 77

Pasangan 77

1. Individu punya perencanaan baru, demikian juga pemerintah

2. Sетиa harus menyusun perencanaan baru sesuai tanggung jawab

\section{Analisis}

Kata semua pada kalimat kedua merujuk pada kata individu dan pemerintah berhubungan secara kohesi anafora pronomina persona

\section{Aspek Katafora}

Aspek kohesi katafora pada teks bacaan tersebut terdapat pada pasangan kalimat 62 dan 67. Pemarkah yang digunakan adalah pronomina persona sebanyak satu pemarkah dan pronomina demonstratif sebanyak satu. Dari data di atas dapat disimpulkan bahwa penulis tajuk rencana tersebut kurang maksimal menggunakan aspek kohesi anafora, hal itu terlihat dari sebanyak 18 pasangan kalimat hanya terdapat 2 pasangan yang memiliki kohesi katafora.

Contoh: Data 62

Pasangan 62

1. Manusia lalu menuliskan hukum dan hasil pengamatan yang kemudian menjadi pedoman untuk membuat dan berbuat sesuatu.
2. Iklim dan cuaca dipolakan dan menjadi pedoman hidup, pedoman bekerja, dan perjalanan.

\section{Analisis}

Kata sesuatu pada kalimat pertama merujk pada seluruh kalimat kedua, berhubungan secara katafora pronominal persona.

\section{Data 8. Deskripsi Data Analisis Tajuk Rencana VIII: Lalu Lintas Menyeramkan \\ Contoh: Data 84 \\ Pasangan 84}

1. Seperti kita baca di harian ini kemarin, pertumbuhan jumlah kendaraan sebesar 8 persen per tahun, sementara pertumbuhan luas jalan hanya 0,01 persen per tahun.

2. Sungguh perbandingan yang amat tidak seimbang.

\section{Analisis}

Kata seimbang pada kalimat kedua merujuk pada klausa pertumbuhan jumlah kendaraan sebesar 8 persen per tahun, semnetara pertumbuhan luas jalan hanya 0,01 persen per tahun, berhubungan secara anafora dengan pemarkah pronomina komparatif.

\section{Aspek Katafora}

Dari 7 pasangan kalimat yang mempunyai kohesi, hanya terdapat dua pasangan kalimat yang dipadukan dengan kohesi katafora yaitu pasangan kalimat nomor 85 dan 90. Data ini menunjukkan bahwa kohesi katafora tidak digunakan secara dominan untuk memadukan kepaduan kalimat. Pemarkah yang digunakan adalah pronomina persona dan demonstratif, masing-masing satu pemarkah, hal ini menunjukkan bahwa penulis tajuk rencana ini kurang memandang penting penggunaan kohesi katafora dan pronomina persona.

Contoh: Data 85

Pasangan 85

1. Yang lebih buruk lagi, industri otomotif yang tidak kita memiliki 
sendiri terus meningkatkan target penjualan

2. Untuk DKI Jakarta saja, angka pertambahan mobil per hari 186 unit dan untuk motor 986 unit.

\section{Analisis}

Kata lebih buruk pada kalimat pertama merujuk pada frasa angka pertambahan mobil per hari 186 unit dan untuk motor 986 unit Berhubungan secara katafora dengan pemarkah pronomina komparatif.

Data 9. Deskripsi Data Analisis Tajuk Rencana IX: Menyelamatkan Bumi Kita Contoh: Data 104

Pasangan 104

1. Kita tak boleh lupa, sebagian penduduk kita masih menggantungkan hidup di sektor ini.

2. Di mana mereka akan ditampung?

\section{Analisis}

Kata mereka pada kalimat ketiga merujuk pada frasa sebagian penduduk pada kalimat kedua, berhubungan secara kohesi anafora dengan pemarkah pronomina persona.

\section{Aspek Katafora}

Teks wacana tajuk rencana di atas tidak mempunyai aspek kohesi katafora. Secara umum kepaduan wacana tajuk rencana di atas tidak dipadukan dengan kohesi katafora.

Data 10. Deskripsi Data Analisis Tajuk Rencana X: Pengisian Jabatan Publik

Contoh: Data 123

Pasangan 123

1. Agenda itu seharusnya menjadi perhatian sehingga kekosongan komisioner Komis Yudisial tidak perlu terjadi.

2. Kelambanan dalam pengisian jabatan itu juga bisa menimbulkan berbagaipenafsiran soal eksistensi Komisi Yudisial yang perannya strategis.

\section{Analisis}

Kata itu pada kalimat kedua merujuk pada frasa komisioner Komisi Yudisial pada kalimat pertama, berhubungan secara anafora pronomina demonstratif.

Kata - nya pada kalimat kedua merujuk pada frasa komisioner Komisi Yudisial pada kalimat pertama, berhubungan secara anafora dengan penanda pronomina persona.

\section{Aspek Katafora}

Teks wacana tajuk rencana di atas tidak mempunyai aspek kohesi katafora, dengan kata lain bahwa aspek kohesi katafora tidak mempunyai peran dominan dalam memadukan antarkalimat.

\section{Data 11. Deskripsi Data Analisis Tajuk} Rencana XI: Lindungi Anak-Anak Kita Contoh: Data 135

Pasangan 135

1. Dalam setiap kerusuhan dan konflik, anak dan perempuan menjadi korban paling menderita.

2. Mereka tidak mampu melawan, tidak saja karena faktor kelemahan fisik, tetapi juga tidak adanya ruang bagi kelemahlembutan dalam setiap konflik yang beraroma keras dan macho.

\section{Analisis}

Kata mereka pada kalimat kedua merujuk pada kata anak dan perempuan pada kalimat pertama. Berhubungan secara anafora dengan pemarkah pronomina persona

\section{Aspek Katafora}

Dari 6 pasangan yang memiliki kohesi, hanya terdapat 2 pasangan kalimat yang keutuhan kalimat-kalimatnya dipadukan dengan kohesi katafora. Kohesi katafora tersebut terdapat pada pasangan kalimat nomor 138. Data ini menunjukkan bahwa kohesi katafora tidak digunakan secara dominan untuk memadukan kalimatkalimat di dalam wacana tersebut, namun keberadaan aspek kohesi katafora akan 
membantu pembaca memahami isi wacana lebih utuh.

\section{Contoh: Data 138}

\section{Pasangan 138}

1. Ajakan imperatif ini akhirnya kembali pada apa yang bisa kita lakukan, sekarang dan di sini.

2. Gerakan Hari Tanpa TV 25 Juli, niscaya relevan, menjadi penanda dan awal perhatian kepada anak.

\section{Analisis}

Kata ini pada kalimat pertamamerujuk pada frasa Gerakan Hari Tanpa TV 25 Juli pada kalimat kedua, berhubungan secara katafora dengan penanda pronomina demonstratif.

\section{Data 12. Deskripsi Data Analisis Tajuk Rencana XII: Terjebak Politik Dagang Contoh: Data 145 \\ Pasangan 145}

1. Tahun 2010 digelar 244 pemilu kepala daerah, dengan rincian 7 pemilihan gubernur, 202 pemilihan bupati, dan 35 pemilihan wali kota.

2. Biaya yang dibutuhkan untuk 244 pemilihan itu mencapai Rp 4 triliun, di luar biaya yang harus disiapkan kandidat.

\section{Analisis}

Kata itu pada kalimat kedu merujuk pada kata pemilu kepada daerah pada kalimat pertama, berhubungan secara anafora pronomina demonstratif.

\section{Aspek Katafora}

Dari 23 pasangan kalimat hanya terdapat 1 pasangan kalimat yang menggunakan aspek kohesi katafora. Aspek kohesi ini digunakan pada pasangan kalimat nomor 150. Kegunaan aspek kohesi katafora kurang mendapat perhatian penulis untuk memadukan hubungan antarkalimat dalam wacana tersebut.

Contoh: Data 150

\section{Pasangan 150}

1. Memang bisa dipertanyakan dari mana biaya politik itu diperoleh.

2. Biaya politik memang tidak harus ditanggung oleh kandidat karena faktanya mereka bisa menggalang dana dari simpatisan.

\section{Analisis}

Kata itu pada kalimat pertama merujuk pada kata biaya politik pada kalimat kedua, berhubungan secara katafora pronomina demonstratif.

\section{Deskripsi Data Aspek Kohesi Anafora dan Katafora Seluruh Judul}

Tabel 2. Rekapitulasi Analisis Aspek Kohesi Anafora Seluruh Judul

\begin{tabular}{|c|c|c|c|c|c|c|c|c|c|c|}
\hline \multirow{2}{*}{ No } & \multirow[t]{2}{*}{ Kode Judul } & \multirow{2}{*}{$\begin{array}{l}\text { Jml } \\
\text { Prgf }\end{array}$} & \multirow{2}{*}{$\begin{array}{l}\text { Jml } \\
\text { P.K }\end{array}$} & \multicolumn{3}{|c|}{ Jumlah } & \multirow{2}{*}{ Jml } & \multicolumn{3}{|c|}{ Persentase } \\
\hline & & & & $\mathrm{PP}$ & PD & PK & & $\mathrm{PP}$ & PD & PK \\
\hline 1 & $\begin{array}{l}\text { Expo dan Pengakuan atas } \\
\text { China }\end{array}$ & 8 & 11 & 1 & 1 & - & 2 & 1.5 & 1.5 & - \\
\hline 2 & $\begin{array}{l}\text { Dana Talangan untuk } \\
\text { Yunani }\end{array}$ & 10 & 6 & 1 & - & - & 1 & 1.5 & - & - \\
\hline 3 & Pergolakan di Atap Dunia & 7 & 13 & 4 & 2 & - & 6 & 6.0 & 2.9 & - \\
\hline 4 & Peringatan Keras bagi AS & 9 & 13 & 2 & 5 & - & 7 & 2.9 & 7.5 & - \\
\hline 5 & $\begin{array}{l}\text { Masihkah Raja Jadi } \\
\text { Penentu }\end{array}$ & 8 & 12 & - & 4 & - & 4 & - & 6.0 & - \\
\hline 6 & Partai Harus Berkoalisi & 11 & 6 & 3 & 2 & - & 5 & 4.5 & 2.9 & - \\
\hline 7 & $\begin{array}{l}\text { Perubahan Cuaca dan } \\
\text { Perencanaan }\end{array}$ & 8 & 18 & 2 & - & - & 2 & 2.9 & - & - \\
\hline 8 & Lalu Lintas Menyeramkan & 11 & 15 & 1 & 3 & 2 & 6 & 1.5 & 4.5 & 2.9 \\
\hline 9 & $\begin{array}{l}\text { Menyelamatkan Bumi } \\
\text { Kita }\end{array}$ & 10 & 15 & 2 & 3 & 1 & 6 & 2.9 & 4.5 & 1.5 \\
\hline
\end{tabular}




\begin{tabular}{|c|c|c|c|c|c|c|c|c|c|c|}
\hline \multirow{2}{*}{ No } & \multirow[t]{2}{*}{ Kode Judul } & \multirow{2}{*}{$\begin{array}{l}\text { Jml } \\
\text { Prgf }\end{array}$} & \multirow{2}{*}{$\begin{array}{l}\text { Jml } \\
\text { P.K }\end{array}$} & \multicolumn{3}{|c|}{ Jumlah } & \multirow{2}{*}{ Jml } & \multicolumn{3}{|c|}{ Persentase } \\
\hline & & & & PP & PD & PK & & PP & PD & PK \\
\hline 10 & Pengisian Jabatan Publik & 8 & 15 & 4 & 8 & - & 12 & 6.0 & 11.9 & - \\
\hline 11 & Lindungi Anak-Anak Kita & 11 & 17 & 4 & - & - & 4 & 6.0 & - & - \\
\hline 12 & Terjebak Politik Dagang & 8 & 23 & 3 & 7 & 3 & 13 & 4.5 & 10.4 & 4.5 \\
\hline & Jumlah & 98 & 164 & 27 & 34 & 6 & 67 & & & \\
\hline
\end{tabular}

Keterangan:

$\begin{array}{ll}\text { - PP } & =\text { Pronomina Persona } \\ \text { - PD } & =\text { Pronomina Demonstratif } \\ \text { - PK } & =\text { Pronomina Komparatif }\end{array}$

\section{Aspek Kohesi Anafora}

Tabel di atas (Tabel 2) menunjukkan penggunaan aspek kohesi anafora seluruh teks wacana tajuk rencana yang diteliti sebanyak 164 pasangan kalimat. Dari 164 pasangan kalimat terdapat 67 pasangan kalimat yang mempunyai aspek kohesi anafora. Dari tabel tersebut diperoleh informasi bahwa semua teks wacana tajuk rencana mempunyai aspek kohesi anafora dalam membentuk kepaduan kalimatkalimatnya, namun penggunaan pemarkah lebih didominasi oleh pronomina demonstratif. Dari seluruh judul dapat ditemukan bahwa penggunaan pronomina demonstratif sebanyak 34 kali atau sebesar 50,7 persen, pronomina persona sebanyak 27 kali atau 40,3\% dari keseluruhan penggunaan pemarkah.

Data tersebut juga memberi gambaran bahwa penggunaan pemarkah pronomina komparatif sangat kecil, yaitu sebanyak 6 kali atau sebesar 9,0 persen dari seluruh penggunaan pemarkah. Gambaran lain yang diperoleh dari data tersebut adalah ditemukannya pemakaian aspek anafora yang kurang dominan pada beberapa judul tajuk rencana. Tajuk rencana yang memiliki aspek kohesi anafora sedikit adalah tajuk rencana nomor 2, 7 dan 11 .

Dari data tersebut, dapat disimpulkan bahwa penggunaan aspek kohesi anafora penting guna membentuk kepaduan antarkalimat.

Tabel 3. Rekapitulasi Analisis Aspek Kohesi Katafora Seluruh Judul

\begin{tabular}{|c|c|c|c|c|c|c|c|c|c|c|}
\hline \multirow{2}{*}{ No } & \multirow[t]{2}{*}{ Kode Judul } & \multirow{2}{*}{$\begin{array}{l}\text { Jml } \\
\text { Prgf }\end{array}$} & \multirow{2}{*}{$\begin{array}{l}\text { Jml } \\
\text { P.K }\end{array}$} & \multicolumn{3}{|c|}{ Jumlah } & \multirow{2}{*}{ Jml } & \multicolumn{3}{|c|}{ Persentase } \\
\hline & & & & PP & PD & PK & & PP & PD & PK \\
\hline 1 & $\begin{array}{l}\text { Expo dan } \\
\text { Pengakuan atas } \\
\text { China }\end{array}$ & 8 & 11 & - & 2 & - & 2 & - & 14.3 & - \\
\hline 2 & $\begin{array}{l}\text { Dana Talangan } \\
\text { untuk Yunani }\end{array}$ & 10 & 6 & - & 1 & - & 1 & - & 7.2 & - \\
\hline 3 & $\begin{array}{l}\text { Pergolakan di Atap } \\
\text { Dunia }\end{array}$ & 7 & 13 & - & - & - & 0 & - & - & - \\
\hline 4 & $\begin{array}{l}\text { Peringatan Keras } \\
\text { bagi AS }\end{array}$ & 9 & 13 & 1 & 2 & - & 3 & 7.2 & 14.3 & - \\
\hline 5 & $\begin{array}{l}\text { Masihkah Raja Jadi } \\
\text { Penentu }\end{array}$ & 8 & 12 & - & 2 & - & 2 & - & 14.3 & - \\
\hline 6 & $\begin{array}{l}\text { Partai Harus } \\
\text { Berkoalisi }\end{array}$ & 11 & 6 & - & - & - & 0 & - & - & - \\
\hline 7 & $\begin{array}{l}\text { Perubahan Cuaca } \\
\text { dan Perencanaan }\end{array}$ & 8 & 18 & 1 & 1 & - & 2 & 7.2 & 7.2 & - \\
\hline 8 & $\begin{array}{l}\text { Lalu Lintas } \\
\text { Menyeramkan }\end{array}$ & 11 & 15 & - & 1 & 1 & 2 & - & 7.2 & 7.2 \\
\hline 9 & $\begin{array}{l}\text { Menyelamatkan } \\
\text { Bumi Kita }\end{array}$ & 10 & 15 & - & - & - & 0 & - & - & - \\
\hline
\end{tabular}




\begin{tabular}{|c|c|c|c|c|c|c|c|c|c|c|}
\hline \multirow{2}{*}{ No } & \multirow[t]{2}{*}{ Kode Judul } & \multirow{2}{*}{$\begin{array}{l}\text { Jml } \\
\text { Prgf }\end{array}$} & \multirow{2}{*}{$\begin{array}{l}\text { Jml } \\
\text { P.K }\end{array}$} & \multicolumn{3}{|c|}{ Jumlah } & \multirow{2}{*}{ Jml } & \multicolumn{3}{|c|}{ Persentase } \\
\hline & & & & PP & PD & PK & & PP & PD & PK \\
\hline 10 & $\begin{array}{l}\text { Pengisian Jabatan } \\
\text { Publik }\end{array}$ & 8 & 15 & - & - & - & 0 & - & - & \\
\hline 11 & $\begin{array}{l}\text { Lindungi Anak- } \\
\text { Anak Kita }\end{array}$ & 11 & 17 & - & 1 & - & 2 & - & 14.3 & - \\
\hline 12 & $\begin{array}{l}\text { Terjebak Politik } \\
\text { Dagang }\end{array}$ & 8 & 23 & 1 & - & - & 1 & 7.2 & - & \\
\hline & Jumlah & 98 & 164 & 3 & 10 & 1 & 14 & & & \\
\hline & Persentase & & & & & & & 21,42 & 71,43 & 7.14 \\
\hline
\end{tabular}

\section{Keterangan:}

- PP

- PD

$=$ Pronomina Persona

- PK

$=$ Pronomina Demonstratif

$=$ Pronomina Komparatif

\section{Aspek Kohesi Katafora}

Dari tabel di atas (Tabel 3.) diperoleh informasi bahwa data yang diteliti sebanyak 164 pasangan kalimat dan penggunaan aspek kohesi katafora dari seluruh teks wacana tajuk rencana yang diteliti sebanyak 14 kali. Hal ini menunjukkan bahwa penggunaan aspek kohesi katafora kurang menjadi prioritas penulis tajuk rencana dalam memadukan antarkalimat.

Data ini juga menunjukkan bahwa tidak semua judul tajuk rencana yang diteliti memiliki kepaduan dengan aspek kohesi katafora. Dari 12 judul teks wacana tajuk rencana terdapat 4 teks wacana tajuk rencana yang tidak memiliki aspek kohesi katafora. Dengan demikian, aspek kohesi katafora terdapat pada 8 judul teks tajuk rencana atau sebesar $66,66 \%$
Penggunaan pemarkah masih diprioritaskan dengan memakai pronomina demonstratif. Dari 14 kali kemunculan aspek kohesi katafora, pemakaian pemarkah pronomina demonstratif sebanyak 10 kali atau sebanyak 71,42\%, pronomina persona sebanyak $3 \mathrm{kali}$ atau $21,42 \%$ dan pronomina komparatif sebanyak satu kali atau $7,14 \%$ dari total penggunaan pemarkah aspek kohesi katafora.

Dari seluruh uraian di atas dapat dikatakan bahwa penggunaan aspek kohesi katafora bukan merupakan aspek yang menjadi prioritas penulis dalam menyusun kepaduan kalimat, namun demikian aspek kohesi katafora menurut pendapat penulis tetap penting digunakan dalam menyusun kalimat. Aspek kohesi tersebut dapat membantu pembaca tajuk rencana mendalami isi wacana.

\section{Deskripsi Data Hasil Analisis Aspek Kohesi Anafora dan Katafora}

Tabel 4. Rekapitualsi Hasil Analisis Aspek Kohesi Anafora dan Katafora

\begin{tabular}{|c|c|c|c|c|c|c|c|c|c|c|}
\hline \multirow{3}{*}{ No } & \multirow{3}{*}{$\begin{array}{l}\text { Jml } \\
\text { Data } \\
\text { (Pas. } \\
\text { Kal) }\end{array}$} & \multirow{3}{*}{$\begin{array}{c}\text { Aspek } \\
\text { Analisis }\end{array}$} & & & & \multirow{3}{*}{$\begin{array}{c}\text { Jumlah } \\
\text { Total }\end{array}$} & \multirow{2}{*}{\multicolumn{3}{|c|}{ Persentase }} & \multirow{3}{*}{$\begin{array}{c}\text { Total } \\
\text { Per- } \\
\text { senta } \\
\text { se } \\
\end{array}$} \\
\hline & & & \multicolumn{3}{|c|}{ Jumlah } & & & & & \\
\hline & & & PP & PD & PK & & $\mathbf{P P}$ & PD & PK & \\
\hline 1 & \multirow{3}{*}{164} & Anafora & 27 & 34 & 6 & $67(\mathbf{4 0 , 4} \%)$ & 33.3 & 41.9 & 7.4 & 82.71 \\
\hline \multirow{2}{*}{2} & & Katafora & 3 & 10 & 1 & $14(\mathbf{8 , 5 4 \% )}$ & 3.70 & 12,34 & 1.2 & 17.28 \\
\hline & & Jumlah & 30 & 44 & 7 & $81(49,39)$ & 37.04 & 54.32 & 8.64 & 100 \\
\hline
\end{tabular}


Keterangan:

- PP

- PD

- PK
$=$ Pronomina Persona

$=$ Pronomina Demonstratif

$=$ Pronomina Komparatif

\section{PEMBAHASAN}

Berdasarkan tabel di atas (Tabel 4.) diperoleh informasi bahwa dari data sebanyak 164 pasangan kalimat terdapat 81 pasangan kalimat atau $49,39 \%$ yang menggunakan kepaduan dengan kohesi anafora dan katafora. Sebanyak 67 pasangan kalimat atau $40,48 \%$ menggunakan kohesi anafora dan sebanyak 14 pasangan kalimat atau 8,54\% menggunakan kohesi katafora. Dari jumlah tersebut ditemukan bahwa aspek kohesi anafora digunakan sebanyak $82,71 \%$ dan aspek kohesi katafora muncul sebanyak $17,28 \%$.

Dari penggunaan pemarkah dapat dipaparkan bahwa pemarkah yang digunakan pada kalimat yang dipadukan dengan aspek kohesi anafora adalah: (1) pemarkah pronomina persona digunakan sebanyak 27 kali atau sebanyak 33, 3\%, (2) pemarkah pronomina demonstratif muncul sebanyak 34 kali atau sebanyak 41,9\%, dan (3) pemarkah pronomina komparatif sebanyak 6 kali atau sebanyak 7,4\% dari keseluruhan kemunculan pemarkah.

Pemarkah yang digunakan dalam aspek kohesi katafora adalah sebagai berikut, 1) pemarkah pronomina persona muncul 3 kali atau sebanyak $3.70 \%, 2$ ) pemarkah pronomina demonstratif muncul 10 kali atau sebanyak $12.34 \%$, dan 3) pemarkah pronomina komparatif muncul 1 kali atau sebanyak 1,2\% dari keseluruhan kemunculan pemarkah.

Dari seluruh penggunaan pemarkah dapat diketahui bahwa pemarkah pronomina persona muncul 30 kali atau $37,04 \%$, pronomina demonstratif muncul 44 kali atau $54,32 \%$ dan pemarkah pronomina komparatif muncul 7 kali atau $8,64 \%$. Data ini menunjukkan bahwa pemarkah pronomina demonstratif mempunyai peran yang paling dominan di antara ketiga pemarkah yang digunakan.
Menurut paparan di atas dapat disimpulkan bahwa dari keseluruhan judul, aspek kohesi anafora muncul sebagai penanda kohesi dan membentuk kalimat menjadi padu, sedangkan aspek katafora hanya muncul pada 8 judul dari 12 judul tajuk rencana atau sebanyak $66.66 \%$.

\section{SIMPULAN}

Dari hasil analisis dan pembahasan di atas, dapat disimpulkan bahwa

1. Kepaduan atau kohesi suatu kalimat ditentukan dengan penggunaan aspek kohesi. Aspek kohesi yang membentuk kepaduan antarkalimat tersebut antara lain aspek kohesi anafora dan katafora.

2. Dari hasil penelitian dari tajuk rencana koran Kompas ditemukan bahwa aspek kohesi anafora lebih banyak digunakan atau muncul dibandingkan dengan aspek kohesi katafora dalam pasangan kalimatpasangan kalimat yang diteliti. Hal ini menunjukkan bahwa penulis tajuk rencana koran Kompas lebih mempertimbangkan aspek kohesi anafora untuk membuat kalimat menjadi padu, selain itu aspek anafora lebih mudah dipahami.

3. Dari hasil penelitian dapat disimpulkan bahwa aspek kohesi anafora mempunyai peran yang lebih penting dibandingkan aspek kohesi katafora dalam memadukan kalimat. Dari 164 data penelitian ditemukan 67 pasangan kalimat memiliki kohesi anafora atau sebanyak 40,48\% dan hanya 14 pasangan kalimat berkohesi katafora atau 8,54\%. Aspek kohesi anafora digunakan secara dominan dalam membangun kepaduan kalimat.

4. Dari penggunaan pemarkah, dapat ditemukan bahwa pemarkah pronomina demonstratif sebanyak 54,32\% lebih sering muncul dalam kalimat 
yang berkohesi. Hal ini menunjukkan bahwa pemarkah pronomina demonstratif mempunyai peran penting di dalam membentuk kepaduan kalimat.

5. Jadi, dari penjelasan di atas dapat diambil simpulan bahwa tajuk rencana koran Kompas cenderung lebih banyak dan dominan menggunakan aspek kohesi anafora dan pemarkah pronomina demonstratif dibandingkan aspek kohesi katafora dan pemarkah lainnya.

\section{PERSANTUNAN}

Peneliti mengucapkan terima kasih kepada berbagai pihak yang telah membantu dalam proses penelitian ini.

\section{DAFTAR RUJUKAN}

Arifin, E. Z., dkk. 2015. Wacana Transaksional dan Interaksional dalam Bahasa Indonesia. Jakarta: Pustaka Mandiri.

Arikunto, Suharsimi. 2009. Dasar-Dasar Evaluasi Pendidikan. Jakarta: Bumi Aksara.

Baryadi, P. 2002. Dasar-Dasar Analisis Wacana dalam Ilmu Bahasa. Yogyakarta: Pustaka Gondho Suli.

Chaer, A. 2010. Bahasa Jurnalistik. Jakarta: Rineka Cipta.

-------. 2002. Pengantar Semantik Bahasa Indonesia. Jakarta: ineka Cipta.

Endraswara, Suwardi. 2004. Metodologi Penelitian Sastra: Epistemologi, Model,. Teori dan Aplikasi. Yogyakarta: Pustaka Widyatama.

Halliday, M.A.K. dan Ruqaiya H. 1979. Cohesion in English. London: Longman.

------- 1994. Language, Context, and Text: Aspect of Language in a Social Perspective. Yogyakarta: Gajah Mada University Press.

Mulyana. 2005. Kajian Wacana: Teori Metode dan Aplikasi PrinsipPrinsip Wacana. Yogyakarta: Penerbit Tiara Wacana.
Tarigan, H. G. 2009. Pengajaran Wacana. Bandung: Penerbit Angkasa.

Zaimar, O. K. S. dan Ayu Basuki H. 2009. Telaah Wacana. Jakarta:The Intercultural Institute.

\section{Surat Kabar:}

Kompas, Jakarta, Senin 3 Mei 2010

Kompas, Jakarta, Selasa 4 Mei 2010

Kompas, Jakarta, Rabu 5 Mei 2010

Kompas, Jakarta, Kamis 6 Mei 2010

Kompas, Jakarta, Jumat 7 Mei 2010

Kompas, Jakarta, Sabtu 8 Mei 2010

Kompas, Jakarta, Senin 19 Juli 2010

Kompas, Jakarta, Selasa 20 Juli 2010

Kompas, Jakarta, Rabu 21 Juli 2010

Kompas, Jakarta, Kamis 22 Juli 2010

Kompas, Jakarta, Jumat 23 Juli 2010

Kompas, Jakarta, Sabtu 24 Juli 2010 